\title{
Kepadatan Populasi Ikan Gelodok Di Hutan Mangrove Desa Penunggul Kecamatan Nguling Kabupaten Pasuruan
}

\author{
Population of Gelodok Fish at Mangrove Forest of Penunggul Villave, \\ Nguling District, Pasuruan
}

\author{
Moch. Chasan Basri ${ }^{1 *}$, Hari Santoso $^{2 * *}$, Saimul Laili ${ }^{3}$ \\ Jurusan Biologi Fakultas Matematika dan Ilmu Pengetahuan Alam Universitas Islam Malang, Indonesia
}

\begin{abstract}
ABSTRAK
Hutan mangrove merupakan salah satu ekosistem daerah pantai terutama pantai utara dan banyak di temui ikan Gelodok di sekitar ekositem ini. Organisme tersebut merupakan salah satu fauna penyusun ekositem mangrove. Tujuan penelitian ini untuk mengetahui kepadatan dan kemelimpahan populasi ikan Gelodok kawasan mangrove desa Penunggul Kecamatan Nguling. Penelitian ini menggunakan metode purposive sampling dari tiga stasiun dan setiap stasiun terdapat tiga plot dengan ulangan tiga kali dalam setiap plot. Hasil penelitian menunjukkan bahwa kepadatan ikan gelodok di kawasan hutan mangrove desa Nguling rata-rata pada stasiun 1 adalah 3, di satsiun 2; 2 dan 3; 1. Pada stasiun 1 terdapat tiga spesies yaitu Baleopthalmus boddarti, Periopthalmus dipus, Periophthalmus Gracilis , stasiun 2 terdapat dua spesies yaitu Baleopthalmus boddarti, Periophthalmus Gracilis dan stasiun 3 terdapat tiga spesies yaitu Baleopthalmus boddarti, Periopthalmodon schlosseri, Periopthalmus dipus. Perbedaan hasil penelitian, kondisi lingkungan dan faktor abiotik mempengaruhi kepadatan ikan Gelodok di kawasan mangrove, sehingga pada stasiun 1 diperoleh kepadatan lebih tinggi.
\end{abstract}

Kata kunci: ikan Gelodok, hutan mangrove, kepadatan populasi

\begin{abstract}
Mangrove forests are the one of the coastal ecosystems; especially the northern coast and many are founded in the surrounding fish ecosystems. That organism is the one of the fauna which mangrove ecosystem constituent. The aim of this study was to determine the density and abundance of the population of Gelodok fish at mangrove areas in Penunggul Village, Nguling District. This study used a purposive sampling method from three stations and each station has three plots and three replications in each plot. The results showed that the density of frog fish in the mangrove forest area of Nguling village at station 1 was 3 as well as at station 2 and 3 respectively 2 and 1. At station 1 there were three species, namely Baleopthalmus boddarti, Periopthalmus dipus, Periophthalmus Gracilis, station 2, there were two species; Baleopthalmus boddarti, Periophthalmus Gracilis, and station 3 there were three species namely Baleopthalmus boddarti, Periopthalmodon schlosseri, Periopthalmus dipus. The differences in the results of the study, environmental conditions and abiotic factors influence the density of fish in the mangrove area and at the station 1 the density is highe.
\end{abstract}

Keywords: Gelodok fish, mangrove forest, population

*) Moch Chasan BAsri, Jurusan Biologi FMIPA UNISMA, Jl. MT Haryono 193, Malang 65144 Telp. 08155502949 , email: etshasanbasri@gmail.com

**) Drs. H. Hari Santoso, M.Biomed, Jurusan Biologi FMIPA UNISMA, Jl. MT Haryono 193, Malang 65144 Telp. 082331449560 E-mail: Harisantoso.m.biomed@gmail.com

Diterima Tanggal 29 Juli 2019 - Diterbitkan Tanggal 25 Januari 2020 


\section{Pendahuluan}

Hutan Mangrove merupakan karakteristik yang khas sebagai salah satu sistem hutan tropis, serta merupakan salah satu ekosistem pantai yang penting. Hutan mangrove juga di juluki sebagai hutan payau karena sebagian besar tanaman mangrove tumbuh dan berkembang di air payau, dan banyak juga di temui ikan Gelodok di ekosistem hutan mangrove, serta merupakan salah satu fauna penyusun ekosistem mangrove [1].

Ikan Gelodok merupakan salah satu ikan yang menyerupai amfibi yang dapat bernafas melalui kulit, tenggorokan, dan mulut. Namun pernafasan kulit pada ikan Gelodok di lakukan pada saat lembab atau basah. Selain itu ikan Gelodok mampu menyimpan sejumlah air di rongga ingsangnya sehingga ikan Gelodok mampu berjalan ke daratan karena ingsangnya yang selalu terendam dengan air [2].

Kemelimpahan Ikan Gelodok sangat berpengaruh sehari-hari pada kebiasaan pola makannya [3]. Pada jenis ikan yang bersifat karnivora serta herbivore lingkungan hidupnya di perairan dangkal pada sela-sela ekosistem mangrove, dimana terdapat banyak fitoplankton sebagai makanan ikan Gelodok dalam sehari hari [4].

Kepadatan populasi Ikan Gelodok selalu bergantung pada daya toleransi di saat perubahan lingkungan. Pemanfaatan hutan mangrove yang berlebihan dalam alih fungsi lahan akan mempengaruhi habitat ikan Gelodok dan akan berdampak turunnya produktivitas hutan mangrove.

Dari uraian diatas peneliti tertarik untuk meneliti keterkaitan antara kerapatan dan kepadatan populasi Ikan Gelodok pada ekosistem mangrove di Desa Penunggul Kecamatan Nguling Pasuruan.

\section{Material dan Metode}

\section{Bahan dan Alat}

Alat yang digunakan dalam penelitian ini yaitu Alat tulis, penggaris, tali rafia, sepatu boot, kamera, gunting, thermometer, Hygrometer, $\mathrm{pH}$ meter, meteran, dan refraktometer.

\section{Metode}

Penelitian ini dilakukan secara metode purposive sampling dari 3 stasiun dan setiap stasiun terdapat 3 plot serta 3 kali ulangan dalam setiap plot. Keragaman spesies dalam penelitian menggunakan rumus indeks keanekaragaman [5].

$$
\left(H^{\prime}\right)=-\sum_{t=l}^{s} P i \ln P i
$$

Pembagian stasiun pengambilan sampel antara lain:

- Stasiun 1: Merupakan area hutan mangrove berindikasi baik.

- Stasiun 2: Merupakan area hutan mangrove berindikasi sedang.

- Stasiun 3: Merupakan area hutan mangrove berindikasi buruk.

\section{Cara Kerja}

Prosedur pengambilan sampel sebagai berikut: Disiapkan alat ukur yang akan di gunakan untuk menentukan kondisi mangrove, diukur faktor abiotik menggunakan alat yang telah di siapkan. ditentukan stasiun kondisi mangrove baik, sedang, dan buruk dengan hasil yang telah di ukur menggunakan beberapa parameter abiotik. Setelah menentukan mangrove yang baik, sedang, dan buruk disiapkan beberapa alat untuk membuat plot-plot per stasiun yang telah di tentukan, disiapkan rafia $4 m^{2}$ untuk membuat plot pada setiap stasiun. Dibuat 3 plot dalam satu stasiun yang diambil pada bibir kawasan mangrove, parameter yang telah di tentukan, diamati pada hari berikutnya agar pengambilan data suatu spesies yang masuk dalam plot yang telah ditentukan dapat maksimal, diamati 
pada saat air laut surut, dan dipastikan pengambilan pada waktu siang atau sore hari, diamati dan tentukan spesies yang ada di dalam plot yang telah di tentukan, dihitung spesies yang masuk dalam plot yang telah di buat, dilakukan 3 kali ulangan dalam setiap stasiun pada waktu yang berbeda.

Analisis Data: Analisis biota di dalam penelitian ini menggunakan :

\section{Kepadatan Populasi}

$$
K=\frac{\text { Jumlah Individu Suatu Jenis }}{\text { Luas area pengambilan sampel }}
$$

\section{Kepadatan Relatif}

$$
K R=\frac{K \text { Suatu spesies }}{\sum K} \times 100 \%
$$

\section{Indeks Keanekaragaman}

$$
\left(H^{\prime}\right)=-\sum_{t=l}^{s} P i \ln P i
$$

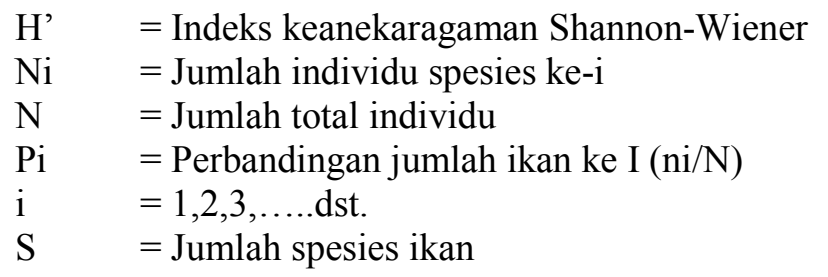

Kriteria hasil keanekaragaman berdasarkan Shannon-Wiener:

$$
\begin{array}{ll}
\mathrm{H}^{\prime} \leq 3,32 & =\text { Keanekaragaman rendah. } \\
3,32 \leq \mathrm{H}^{\prime} \leq 9,97 & =\text { Keanekaragaman sedang. } \\
\mathrm{H}^{\prime} \geq 9,97 & =\text { Keanekaragaman tinggi. }
\end{array}
$$

\section{Hasil dan Diskusi}

Hasil penelitian yang dilakukan di kawasan mangrove desa Penunggul Kecamatan Nguling Kabupaten Pasuruan diperoleh data $\mathrm{pH}$ pada stasiun 1 sebesar 8.6 dan pada stasiun 2 sebesar 8.3 dan stasiun terakhir 8.4. Bagi kehidupan organisme laut pada pH 6-9 merupakan kisaran yang masih dapat ditolerir, oleh karena itu dengan data yang diperoleh merupakan nilai $\mathrm{pH}$ yang mendukung kehidupan pada ikan gelodok di daerah tersebut. Faktor abiotik salinitas pada stasiun 129 ,3ppt, pada stasiun 2 dan 3 mendapatkan hasil data yang sama yaitu sebesar 28,0 ppt. Disolved Oxigen adalah 7,1, sedangkan pada stasiun 1 yaitu 4,4 dan 2,6 pada stasiun lainnya da semakin tinggi oksigen terlarut maka semakin tinggi kepadatan pula organisme yang terdapat di daerah tersebut.

Pada kawasan mangrove Desa Penunggul di dapatkan 5 spesies yaitu: Baleophthalmus boddarti, Periophthalmodon schlosseri, Periophthalmus dipus, Periophthalmus gracilis, Periphthalmus chrysospilos. Stasiun 1, 1, dan 3 mangrove berindikasi masing-masing mangrove baik, mangrove sedang, dan mangrove buruk.

Kepadatan Populasi: Hasil penelitian menunjukkan bahwa pada stasiun 1 kepadatan populasi ikan Gelodok cukup tinggi dibandingkan stasiun ke 2 dan terakhir. Kepadatan populasi stasiun 1 mencapai 3.17 , di banding dengan nilai dari stasiun ke 2 dan ke 3 yang lebih rendah yakni 1.72 dan 1.39. Nilai ini cukup tinggi, membuktikan bahwa kondisi kepadatan mangrove bagus pada stasiun 1. Kemelimpahan pakan tinggi yang dipacu oleh pasang surut air laut pada stasiun 1 yang letaknya di 
e-Jurnal Ilmiah BIOSAINTROPIS (BIOSCIENCE-TROPIC)

Volume 5/ No.: 2 / Halaman 66 - 71 / Januari Tahun 2017

ISSN : 2460-9455 (e) - 2338-2805(p)

bagian depan area mangrove, sehingga organisme dan fitoplankton sebagai makanan ikan Gelodok tetap terpenuhi [6].

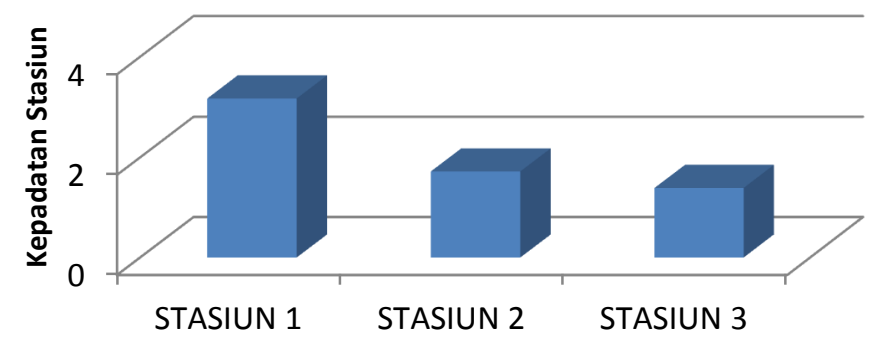

Gambar 1. Kepadatan Populasi Ikan Gelodok

Namun pada stasiun 2 dan 3 yang letaknya pada kondisi mangrovemasing-masing sedang dan buruk serta terletak di bagian mangrove yang tidak jauh dengan daratan, didapatkan hasil data 1.72 dari stasiun 2 dan 1.39 dari stasiun 3. Nilai ini sangat jauh dibandingkan dengan stasiun 1 . Hasil data persentase kepadatan stasiun 2 dan stasiun 3 menggambarkan kondisi mangrove mempengaruhi kehidupan dan pertumbuhan ikan Gelodok. Kawasan yang ditumbuhi oleh mangrove selalu berkaitan dengan kawasan perikanan yang penting, sehingga hilangnya mangrove akan menurunkan produksi perikanan [7]. Penurunan jumlah spesies dalam suatu habitat mempengaruhi jumlah kualitas dan kuantitas ikan Gelodok.

Pada stasiun 2 dan 3, nilai kepadatan yang rendah dikarenakan kurangnya kesediaan pakan ikan gelodok di kawasan mangrove. Kondisi mangrove yang sedang dan buruk yang letaknya tidak jauh dengan daratan dan pasang surut air laut tidak maksimal di stasiun 2 dan 3 sehingga pakan ikan gelodok tidak melimpah dibandingkan dengan stasiun 1, memicu kurangnya kepadatan ikan Gelodok.

Kepadatan Relative: Kepadatan relative yang ada di pantai kawasan mangrove Nguling menunjukkan hasil data yang bevariasi dalam setiap stasiunnya. Beberapa spesies, memliki tingkat kemelimpahan yang tinggi maupun rendah. Kepadatan ikan Gelodok mendapatkan hasil berbedabeda. Pada spesies Baleopthalmus boddarti yang berada di stasiun 2 sangat tinggi hingga mencapai 93\% dibandingkan stasiun 1 dan 3 yang menunjukkan data relative $61 \%$ dan $84 \%$ pada stasiun 3 . Spesies Periopthalmodon schlosseri dari 3 stasiun hanya terdapat pada stasiun 3 yang indikatornya mangrove buruk dan tidak di jumpai pada stasiun 1-2.

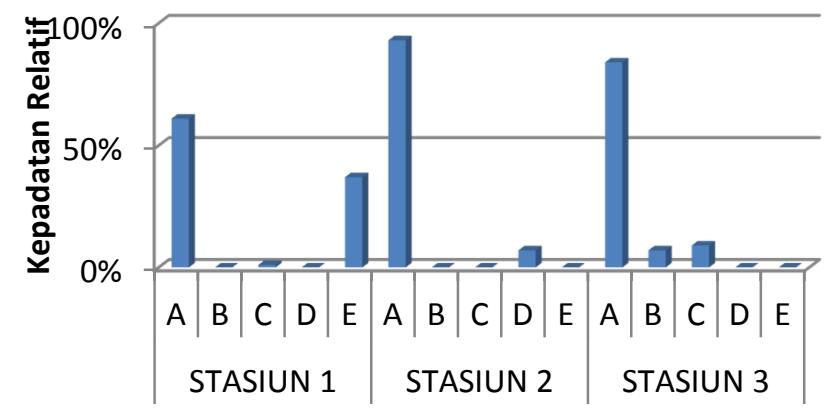

Gambar 2. Kepadatan Relatif Ikan Gelodok 
Demikian juga dengan kepadatan relative spesies Periopthalmus dipus yang lebih dominan di stasiun 3 sebesar 9\% di bandingkan dengan stasiun 1 yang hanya mendapatkan hasil 7\%. Spesies Periophthalmus Gracilis dari 3 stasiun hanya dijumpai di stasiun 2 yang mencapai 5\%. Spesies Periophthalmus chrysospilos hanya di temukan di stasiun 1 dan tidak dijumpai pada stasiun lainnya. Dengan ini nilai kepadatan relative yang tertinggi yaitu spesies Baleopthalmus boddarti pada stasiun 2 dan nilai terendah juga di stasiun 2 pada spesies Periopthalmodon schlosseri, Periopthalmus dan Periophthalmus chrysospilos.

Kepadatan ikan Gelodok terbanyak terdapat pada stasiun I, yaitu terdapat 3 spesies, hal ini dikarenakan kandungan organik yang tinggi pada stasiun 1 dan hutan mangrove yang indikatornya baik. Selain itu, mangrove juga berfungsi sebagai penyedia unsur hara, ekosistemnya merupakan tempat pemijahan (spawning grounds), tempat pengasuhan (nursery grounds) dan tempat mencari makan (feeding grounds) berbagai jenis ikan, udang dan makrozoobenthos [3].

Indeks Keanekaragaman: Diversitas ikan Gelodok di kawasan mangrove desa Penunggul tergolong rendah sehingga pengamatan dilakukan dengan menghitung keanekaragaman untuk mengetahui persebaran 5 spesies pada 3 stasiun yang sudah ditentukan di kawasan mangrove.

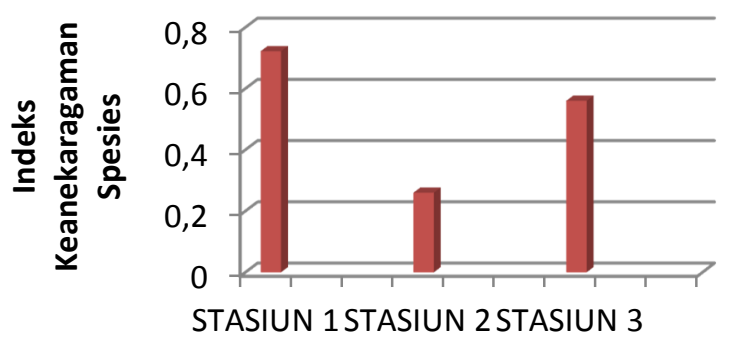

Gambar 3. Indeks Keanekaragaman Ikan Gelodok

Nilai indeks keanekaragaman ukuran $\left(\mathrm{H}^{\prime}\right)$ dari 3 stasiun yang didapatkan bervariasi, pada stasiun 1 nilai keanekaragaman spesies yaitu 0.72 yang lebih tinggi dibandingkan dengan nilai keanekaragaman spesies stasiun 2 dan 3. Pada stasiun 1 persebaran ikan Gelodok dapat dinyatakan beragam karena terdapat 3 spesies yang di temukan dalam stasiun 1. Berbeda dengan stasiun 2 dan 3 yang mendapatkan hasil indeks keragaman spesies 0.26 dan 0.56 yang menggambarkan bahwa pada stasiun 2 dan 3 indeks keragaman spesies ikan Gelodok tergolong rendah dibandingkan dengan stasiun 1. Dalam hasil ini stasiun memiliki kergaman yang paling rendah dari stasiun 1 dan 3.

Perbedaan keragaman antar stasiun dipengaruhi oleh kondisi lingkungan. Semakin baik lingkungan maka semakin banyak keanekaragamannya (semakin banyak spesiesnya), adanya pergantian musim dapat mempengaruhi keragaman spesies dan kondisi makanan [8]. Lingkungan merupakan alasan baik dan rendahnya keanekaragaman. Jika semakin baik kondisi lingkungan mangrove maka semakin banyak pula keanekaragaman dikarenakan beberapa faktor yang mendukung sehingga keragamannya tinggi. Pada stasiun 2 dan 3 yang letaknya di kawasan mangrove buruk serta di perbatasan daratan hal ini menyebabkan faktor abiotic yang kurang bagus dan dipacu dengan kondisi mangrove sehingga berdampak dengan tersediaan makan yang kurang mencukupi. Pasang surutnya yang terlalu tinggi dapat mengurangi organisme atau fitoplankton sebagai pakan ikan Gelodok dikarenakan terseret oleh surutnya air laut.

Keanekaragaman jenis tinggi bila banyak jenis yang mendominasi ekosistem tersebut, dan keanekaragaman jenis rendah bila hanya satu jenis saja yang terdapat di dalamnya mendominasi komunitas tersebut [9]. Tinggi rendahnya keanekaragaman jenis dipengaruhi oleh banyak faktor dan salah satu faktor adalah kualitas lingkungan. 


\section{Kesimpulan}

Dari hasil penelitian ini dapat disimpulkan bahwa di kawasan mangrove merupakan tempat aktivitas ikan Gelodok dalam sehari-hari saat mencari makan, dengan demikian semakin baik kondisi mangrove maka semakin baik pula kepadatan dan keanekaragaman ikan Gelodok. Kepadatan dan keanekaragaman pada stasiun 1 cukup tinggi yang berada di kawasan mangrove baik di bandingkan dengan stasiun 2 dan 3 yang berada di kawasan mangrove yang sedang dan buruk sehingga mendapatkan hasil kepadatan dan keanekaragaman yang rendah.

\section{Daftar Pustaka}

[1] Hutomo, M. dan Naamin, M. 1982. Pengamatan pendahuluan tentang ikan gelodok (Periopthalmus sp) dan catatan singkat tentang Periophthalmus koelteuteri (Pallas). Prosiding Seminar II Ekosistem mangrove. Baturaden.

[2] Polgar, G. dan Lim, R.. 2011. Mudskippers Human Use, Ecotoxicology And Biomonitoring Of Mangrove And Other Soft Bottom Intertidal Ecosystems. Institute of Biological Sciences, Institute of Ocean and Earth Sciences, Faculty of Science, University of Malaya Kuala Lumpur. Malaysia

[3] Redjeki, S. 2013. Komposisi dan kelimpahan ikan di ekosistem mangrove di Kedungmalang, Jepara. Ilmu Kelautan, 18(1): 54-60

[4] Romimohtarto, K., Juwana, S. 2007. Biologi laut. Ilmu pengetahuan tentang biologi laut. Pusat Penelitian dan Pengembangan Oseanografi-LIPI, Jakarta.

[5] Kusmana, C. 1997. Metode survey vegetasi. Penerbit Institut Pertanian Bogor. Bogor.

[6] Gunawan, H dan Anwar, C. 2005. Analisis Keberhasilan Rehabilitasi Mangrove di Pantai Utara Jawa Tengah. Info Hutan Vol. II, No. 4 : 239-248. Badan Litbang Kehutanan. Bogor

[7] Bengen, D.G. dan. Dutton, I.M. 2004. Interaction: Mangroves, Fisheries and Forestry Management in Indonesia. in Northcote. T. G. dan Hartman (Ed), Worldwide Watershed interaction and Management. Blackwell Science. Oxford. UK

[8] Ghozali, T., Muchtadi, D. dan Yaroh. 2004. Peningakatan Daya Tahan Simpan Sate Bandeng (Chanos chanos) dengan Cara Penyimpanan Dingin dan Pembekuan. Infomatek,Vol. 6 Nomor 1. Bandung.

[9] Lloyd, M.and Herald, G.R.J.1964. A Table for Calculating the Equaitability Component of Species Diversity. J. Anim. Biol 33 :217-225. 